\section{REFERENCE NOTES}

1. Linear and Interface Circuits Applications, Texas Instruments. Inc.. Dallas. Texas, 1974. Chapter 3.

2. Precision IC Comparator Runs from 5V Logic Supply. National Semiconductor A pplications Note AN-41. October, 1970.

\section{REFERENCE}

Petrijohn D. Electronic windows. Behavior Research Methods \& Instrumentation. 1975. 7, 351-352.

\section{An inexpensive solid state unit for free-operant avoidance training}

\section{R. J. QUY \\ Lniversity of Keele, Staffordshire, England}

Sidman (1953) described the use of an avoidance training technique in which subjects could delay an aversive stimulus for a prescribed interval by producing an appropriate response. This procedure has been successfully employed in many conditioning studies, including those involving human subjects (Ader \& Tatum. 1961). A valuable synopsis is provided in Sidman (1966).

There are many instruments available on the market which have provision for a Sidman, or free-operant, avoidance schedule. However, the limited requirements of a particular study, or economic considerations might warrant the construction of this simple unit in which standard integrated circuit logic modules are used as the control elements to provide a versatile means of programming an avoidance schedule. A small audio-warning device is suggested as the aversive stimulus.

The circuit diagram is given in Figure 1, and a parts list in Table 1.1 The actual integrated circuit modules used by the author are indicated, but any other compatible packages will suffice. The device was programmed for independent shock-shock and response-

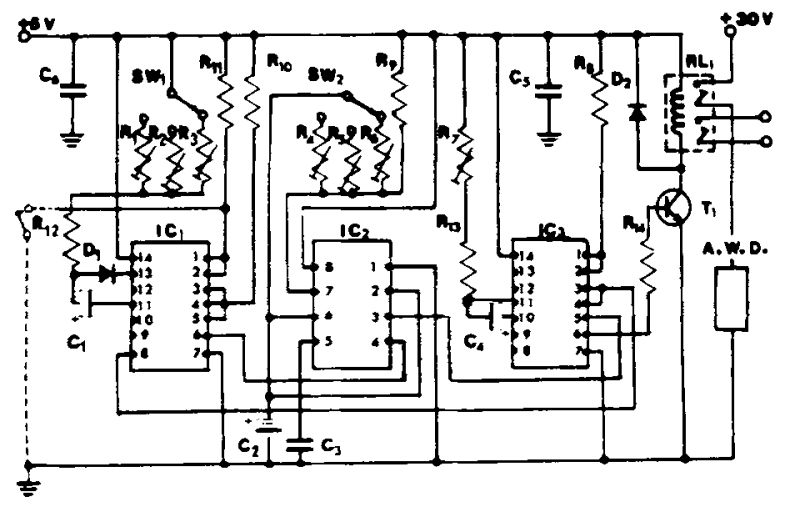

Figure 1. Low-cost circuit for programming a variable free-operant avoidance schedule.
Table 1

List of Components for Free-Operant Avoidance Training Unit

A.W.D. RS 24-V audio-warning device

Cl $1000-\mu \mathrm{F} 16-\mathrm{V}$ electrolytic capacitor

C2 $150-\mu \mathrm{F} 25-\mathrm{V}$ electrolytic capacitor

C3 $\quad .01-\mu \mathrm{F}$ ceramic capacitor

C4 $50-\mu \mathrm{F} 25 \cdot \mathrm{V}$ electrolytic capacitor

C5. C6 .1- $\mathrm{FF}$ ceramic capacitors

D1, D2 IN4148 diodes

IC1 Texas SN74122N retriggerable monostable

IC2 RS Timer A (NE555) integrated circuit timer

IC3 Texas SN74121N monostable

R1, R2, R3, R7 $33 \mathrm{~K} \Omega \quad$ preset resistors

R4, R5, R6 $100 \mathrm{~K} \Omega \quad$ preset resistors

$\mathrm{R} 8, \mathrm{R} 10, \mathrm{R} 11 \quad 2.2 \mathrm{~K} \Omega \quad 5 \%$ resistors

$\begin{array}{lll}\mathrm{R} 9 & \mathrm{~K} \Omega & \mathrm{K} \Omega \text { resistor }\end{array}$

R12, R13, R14 $4.7 \mathrm{~K} \Omega \quad 5 \%$ resistors

RL1 RS 6-V 70- $\Omega$ 2-pole relay

SW1, SW2 1-pole 12-way midget wafer switches T1 $\quad$ BC109 transistor

shock intervals of $5 \mathrm{sec}, 10 \mathrm{sec}$, and $20 \mathrm{sec}$. Shock-shock intervals are selected by SW2: each is set by adjusting the appropriate trimming potentiometer $\mathrm{R} 4, \mathrm{R} 5$, or $\mathrm{R} 6$ while measuring output pulse duration at Pin 3 of IC2 on an oscilloscope or digital timer. Similarly, responseshock intervals are selected by SW1 and are set by adjusting trimming potentiometers RI-R3, measuring the pulse duration at Pin 8 of IC 1 . The range can be easily extended by adding more trimming potentiometers to SW1 and SW2, and, if necessary, increasing the Timing Capacitors $\mathrm{C} 1$ and $\mathrm{C} 2$. Potentiometer R7 varies the shock duration from approximately $250 \mathrm{msec}$ to $1,500 \mathrm{msec}$. If required, an additional potentiometer can be included in the output and calibrated for various stimulus intensities.

The $+5-\mathrm{V}$ power supply should be well stabilized and smoothed. Many suitable logic supply cards are now marketed. However, a 4.5-V to $6-\mathrm{V}$ cell will also drive the unit provided that a check is kept on the voltage under load. The $+30-\mathrm{V}$ supply can be obtained directly from a transformer and full-wave rectifier, no smoothing is necessary.

Logic modules of this type can be falsely triggered by interference spikes as they operate with very fast pulse edges. The circuit should therefore be reasonably compact and mounted inside a metal case which is connected to the earth line. The loads to the response input might also need to be screened. Capacitors $\mathrm{C} 5$ and C6 have been included to guard against transients on the power-supply line.

The two-pole relay RL1 can be used to gate a variety of aversive stimuli and, in addition, to switch a reinforcement marker pulse for an event or cumulative recorder. The author found that a very simple and inexpensive audio-warning device marketed by RS Components Ltd. ${ }^{2}$ provides a convenient and effective aversive stimulus. This device produces a penetrating and unpleasant $2.600 \mathrm{~Hz}$ modulated tone. When 
driven at $30 \mathrm{~V}$. sound intensity was measured at $18 \mathrm{~cm}$ as $100 \mathrm{~dB}$ SPL. Although the range of effectiveness of the device is limited, which is the general disadvantage of noise as an aversive stimulus (Azrin \& Holz, 1966), it is sufficient to offer an alternative means of maintaining an avoidance response in many experimental situations. Several of these devices could be positioned within the environment to increase stimulus effectiveness and approximate a homogeneous sound field.

\section{REFERENCES}

Ader. R., \& TATLM, R. Free-operant avoidance conditioning in human subjects. Journal of the Experimental Analysis of Behavior. 1961, 4. 275-276.
AzRiN. N. H. \& Holz. W. C. Punishment. In W. K. Honig ' Ed.). Uperam behavior: A reas of research and application. New Yurk: Appleton-Century-(rofts. 1960. Pp. 380-447.

Sidman. M. Avoid ance cond itioning with briet shock and no exteroceptive warning signal. Science. 1953, 118, 157-158

Sidman. M. Arollance behavior. In W. K. Honig (Ed.). Operant behavion: Areas of research and application. New York Appleton-Century-Crofts. 1900 . Pp. 448.498.

\section{NOTES}

1. The author would like to thank N. Holimshead for his assistance in constructing this unit.

2. R. S. Components Ltd.. P. O. Box 42- 1.3.1 Epworth Strect. London. EC2P 2HA. England.

(Received for publication November 17. 19-5) 